\title{
Gymnasiets laborationsundervisning i fysik - Vad påverkar lärares val av laborationer?
}

\author{
Simon Holmström, Ann-Marie Pendrill, Urban Eriksson och Nina Reistad \\ Fysiska institutionen, Lunds Universitet, Sverige
}

Vilka faktorer påverkar svenska gymnasielärares laborationsundervisning i fysik? Frågan aktualiseras av den svenska läroplansrevisionen från 2011. I denna studie fick 17 lärare på fyra gymnasieskolor diskutera sin laborationsundervisning i fokusgruppsintervjuer. Baserat på en analys av dessa intervjuer genomfördes en kompletterande enkätundersökning med 66 lärare. Händelselogik användes som analysverktyg för att förstå hur lärarnas laborationsundervisning påverkas av olika faktorer. Resultaten från fokusgrupperna tyder på att lärare uppskattar laborationer som 1) bygger på enkel utrustning, 2) ger ett bra resultat avseende värdet på konstanter, samt 3) laborationer som eleverna tycker om. I enkätundersökningen framstod styrdokumenten som en starkare påverkansfaktor än i fokusgrupperna - men resultaten från båda delarna av undersökningen tyder på att styrdokumenten inte är den viktigaste faktorn i lärares val och upplägg av laborationer.

Nyckelord: fysiklaborationer, gymnasiet, händelselogik, styrdokument

What factors influence Swedish upper secondary teachers' laboratory teaching in physics? This is an issue raised by the curriculum reform of 2011 in Sweden. In this study, 17 teachers at four different upper secondary schools discussed their laboratory teaching in focus group interviews. Based on an analysis of these interviews, a supplementary survey of 66 teachers was conducted. Logic of events was used as an analytical tool to understand how different factors influence teachers' teaching. The results from the focus groups indicate that teachers appreciate laboratory work that 1) are based on simple equipment, 2) provide good values of constants, 3 ) laboratory exercises that the students like. In the survey, the syllabus emerged as a stronger factor of influence than in the focus groups - but, the results from both parts indicate that other factors than the syllabus play a larger role for teachers' choice and layout of laboratory work.

Keywords: physics, laboratory work, upper secondary school, logic of events, syllabus
Artikel

LUMAT General Issue Vol 7 No 1 (2019), 27-58

Mottagen 10 oktober 2018 Accepterad 17 februari 2019 Publicerad 25 februari 2019

Sidor: 32

Referenser: 40

Kontakt:

simjo.homlstrom@gmail.com

https://doi.org/10.31129/ LUMAT.7.1.364 


\section{Inledning, bakgrund och syfte}

\subsection{Inledning}

Den här studien fokuserar på laborationens roll i fysikundervisningen ur ett svenskt gymnasielärarperspektiv, och hur olika faktorer påverkar lärares laborationsundervisning. Studiens syfte aktualiseras med den senaste revisionen av styrdokumenten i fysik för gymnasieskolan i Sverige, Gy11, där experimentella färdigheter, inklusive planering och utvärdering, fått en tydligare roll än tidigare (Skolverket, 2000; Skolverket, 2011a). Detta avspeglas också i att de laborativa momenten i de nationella kursproven som Skolverket erbjuder, har fått en mer framträdande roll efter Gy11 (jfr Skolverket, 2018a). Revisionen 2011 medförde också en starkare betoning på utveckling av elevers förmåga att använda informations- och kommunikationsteknologi (IKT), en betoning som förstärks efter en uppdatering av styrdokumenten 2018 med fokus på digitala färdigheter (Skolverket, 2018b).

\subsection{Bakgrund och litteraturgenomgång}

En återkommande och grundläggande målsättning i skolans laborationsundervisning är att begrepp, teorier och modeller ska kopplas till observationer, mätningar och experiment (Millar, Tiberghien, \& Le Maréchal, 2002; Osborne, 2015; van den Berg, 2013). Målsättningar med laborationsundervisning kan också delas upp i kognitiva mål, affektiva mål och träning av färdigheter (Wellington, 1998), eller ytterligare delas upp i förståelse för vetenskapliga begrepp, intresse och motivation, praktiska färdigheter och förmåga att lösa problem, vetenskapligt tankesätt och förståelse för naturvetenskapens karaktär (Lunetta, Hofstein, \& Clough, 2007). I en europeisk studie av laborationsundervisningen i naturvetenskapliga ämnen på gymnasie- och högskolenivå framkom som ett av de övergripande lärandemålen, att eleverna ska kunna identifiera och bekanta sig med objekt och fenomen, och att en fysiklaboration ofta bygger på att eleven ska lära sig ett bestämt samband eller formel (Tiberghien, Veillard, Le Maréchal, Buty, \& Millar, 2001).

Laborationsundervisningen kan ha olika upplägg, till exempel avseende graden av styrning. Traditionellt bygger en fysiklaboration på att eleven följer lärarens styrda instruktioner, samlar in förbestämda mätdata med en för eleven obekant utrustning, bearbetar mätdata och skriver en rapport efter en bestämd mall (Holmes \& Wieman, 2016). En styrd laborationsundervisning kan kopplas till en grundläggande 
målsättning att förstärka den teoretiska undervisningen och som därmed leder till ett behov av att eleven ska uppnå avsett resultat (Meltzer \& Otero, 2015). Laborationer kan också vara mera öppna och graden av öppenhet kan kategoriseras utifrån frihetsgrader med avseende på: i) problem, ii) genomförande och iii) resultat (Andersson, 1989). Laborationer kan också kategoriseras med avseende på graden av elevens deltagande, från lärarledda demonstrationer, till smågruppslaborationer och individuellt genomförda laborationer (Millar et al., 2002). Styrd och traditionell undervisning har under lång tid kritiserats (tex Meltzer \& Otero, 2015) med rekommendationer att den bör ersättas med mer elevcentrerad undervisning (tex Meltzer \& Thornton, 2012). Jämförelser mellan styrd traditionell laborationsundervisning och en mer öppen laborationsundervisning, visar bland annat att elever utvecklar fler laborativa färdigheter och får en känsla av autonomi vid öppna laborationer (Bergendahl, 2004; Holmes \& Wieman, 2016). Samtidigt kan öppna laborationer var mer tidskrävande och kräver större förkunskaper hos eleven (Holmes \& Wieman, 2016). Kirschner et al. (2006) finner också att en alltför begränsad styrning av undervisningen medför en risk att eleven lär sig fel saker.

Lärarens målsättning kan påverka upplägget på laborationsundervisning. En målsättning kan avspegla en personlig uppfattning hos läraren (jfr Wright, 1983), men undervisningen ska också vara grundad i styrdokumenten. Undervisningen ska bygga på ämnesplanens centrala innehåll, för att läraren ska kunna bedöma elevens kunnande utifrån ämnesplanens kunskapskrav, samtidigt är undervisningsmetoder som leder till dessa mål den enskilde lärarens ansvar (Grettve, Israelsson, Jönsson, 2014). Bedömningen av elevens laborativa prestationer är en problematisk del i lärares undervisning (Gott \& Duggan, 2002). Till problemen hör att en bedömning oftast utgår från elevens skriftliga inlämning och inte på elevens praktiska utförande (Gott \& Duggan, 2002; van den Berg, 2013), och att bedömningen bara påverkar elevens slutbetyg i gränsfall (Ottander \& Grelsson, 2006).

Ett par undersökningar har kategoriserat olika "lärartyper" i fysik, där ett fall studerade lärares användning av IKT i laborationsundervisningen i Grekland (Siorenta \& Jimoyiannis, 2008) och ett annat fall studerade lärares undervisning av hållbar utveckling i Sverige (Engström, 2011). I båda undersökningarna framträder den traditionelle läraren som vanligast, som upprepar sin undervisning år från år och en undervisning som ofta baseras på att lösa uppgifter i läroboken med syfte att täcka kursplanens innehåll (Siorenta \& Jimoyiannis, 2008; Engström, 2011). I båda studierna framkommer också en grupp lärare som var mer benägen att tillämpa andra 
undervisningsmetoder än traditionella metoder, till exempel genom IKT. Engström (2011) finner att olika lärare tolkar styrdokumenten på olika sätt. En stark påverkansfaktor i de grekiska lärarnas undervisning var att förbereda eleven inför nationella slutprov och universitetens inträdesprov (Siorenta \& Jimoyiannis, 2008).

Litteraturgenomgången ovan ger olika exempel på avvägningar en lärare ställs inför vid planeringen och genomförandet av en laboration, och hur olika faktorer påverkar laborationsundervisningen. Samtidigt saknas mer detaljerade beskrivningar av lärares upplägg av laborationsundervisningen och hur olika faktorer påverkar lärares val av laborationer.

\subsection{Syfte}

Ytterst är det den enskilde läraren som planerar och genomför laborationsundervisningen och inledningen ovan belyser en del av den problematik som lärare ställs inför. Holmström et al. (2018) har studerat hur lärare använder tre klassiska laborationer i sin undervisning. Denna studie har sin utgångspunkt i lärares beskrivningar av sina favoritlaborationer med syfte att förstå hur lärare väljer sina favoritlaborationer, samt vilka faktorer som påverkar dessa val.

Frågeställningarna är:

- Hur karaktäriserar gymnasielärare i fysik sina favoritlaborationer?

- Vilka faktorer påverkar lärares laborationsundervisning - och hur?

\section{Metod}

Denna studie är explorativ och undersöker gymnasielärares syn på laborationsundervisningen. Vi ser därför ett behov av en detaljerad beskrivning av lärares syn på laborationsundervisningen, både från ett individuellt och från ett grupp- och skolperspektiv. Datainsamlingen bygger därför på två metoder och baserades i huvudsak på fokusgruppsintervjuer som efterföljdes av en enkätundersökning. Först genomfördes intervjuer med lärare från två skolor. Därefter analyserades frågor och svar och smärre revision av frågorna gjordes inför de två följande intervjuerna, vilket beskrivs närmare i sektion 2.1. Analysen av fokusgruppsintervjuerna användes sedan för att konstruera enkätundersökningen 
som skickades iväg till en större grupp lärare för att få en bredare bild av lärares laborationsundervisning.

Ett sätt att förstå en lärares undervisning, är att se undervisningen som en logisk konsekvens av olika faktorer. Som analysverktyg har vi därför valt att använda händelselogik, vilken studerar människors handlingar ur filosofisk synvinkel. Denna metod är utarbetad av von Wright (1983) och har vidareutvecklats bland annat av Lager-Nyqvist (2003). Händelselogik som analysmetod presenteras i sektion 2.2, tillämpningen av analysverktyget i sektion 2.3 och metoddiskussionen i sektion 2.4.

\subsection{Datainsamling}

Datainsamlingen baserades till största delen på semistrukturerade fokusgruppsintervjuer, vilket ger möjlighet att få fram ett rikt material av åsikter och uppfattningar (Kvale, Brinkmann, \& Torhell, 2009; Stewart, Shamdasani, \& Rook, 2007). Fokusgruppsintervjuer ger både insyn i gruppens och individens inställningar och åsikter, och metoden ger även kunskap om gruppens gemensamma praxis och kan användas för att förstå ett visst beteende (Stewart et al., 2007). I tabell 1 återges medverkande lärare i fokusgrupperna med fingerade namn tillsammans med deras undervisningserfarenhet. Som komplement och för att säkra validiteten genomfördes en enkätundersökning.

Tabell 1. Medverkande lärare i fokusgrupperna.

\begin{tabular}{cc|cc|cc|cc}
\hline \multicolumn{2}{c|}{ Skola 1 } & \multicolumn{2}{c|}{ Skola 2 } & \multicolumn{2}{c|}{ Skola 3 (pilot) } & \multicolumn{2}{c}{ Skola 4 (pilot) } \\
\hline Namn & $\begin{array}{c}\text { Erfahrenhet } \\
\text { (år) }\end{array}$ & Namn & $\begin{array}{c}\text { Erfahrenhet } \\
\text { (år) }\end{array}$ & $\begin{array}{c}\text { Namn } \\
\text { Erfahrenhet } \\
\text { (år) }\end{array}$ & $\begin{array}{c}\text { Namn } \\
\text { Erfahrenhet } \\
\text { (år) }\end{array}$ \\
\hline Adam & 25 & Frida & 10 & Joel & 19 & Nils & 14 \\
Bertil & 19 & Gunnar & 35 & Krister & 19 & Ola & 14 \\
Carl & 19 & Hugo & 14 & Lorentz & 14 & Petter & 30 \\
Eavid & 9 & Iris & 10 & Markus & 10 & Rebecka & 12 \\
\hline
\end{tabular}


Svensk gymnasieundervisning i fysik bedrivs framförallt på två nationella inriktningar: Naturvetenskapliga programmet (NA) och Teknikprogrammet (TE), och som har en gemensam ämnesplan (Skolverket, 2011a). Utöver dessa program finns det också en mindre internationell inriktning under organisationen International Baccalaeureate (IB), med en egen kursplan (IBO; 2014, 2018). Alla tre programmen är representerade i studien.

Studien inleddes som en pilotstudie på två kommunala skolor (skola 3 och 4) i form av semi-strukturerade fokusgruppsintervjuer (Kvale et al., 2009). Intervjuschemat innehöll en inledande fråga om vilken som var lärarens favoritlaboration och varför, och frågor att ställa, om de inte redan kommit upp i samtalet:

- Hur bedöms laborativt arbete? Har ni genomfört Skolverkets laborativa prov?

- Hur används datorn i laborationsundervisningen?

- Hur upplever ni elevers laborativa förkunskaper och förkunskaper i fysik?

Samtalstemat favoritlaborationer visade sig ge upphov konkreta beskrivningar av laborationsundervisningen och gav en insikt om faktorer som lärare uppskattar. Denna fråga användes därför som inledningsfråga i de följande intervjuerna. Övriga frågor behölls också men modifierades något, så att fråga 1 kom att fokusera mer på bedömningen av laborationsrapporter och fråga 3 inkluderade även förkunskaper i matematik.

Kontakt etablerades med tre andra skolor i södra Sverige, varav två (skola 1 och 2) ställde upp för intervju, båda kommunala skolor. Via mejl informerades lärarna om studiens övergripande syfte och de ombads fundera på en favoritlaboration och varför den var en favorit. Intervjuerna genomfördes under uppsluppen stämning på lärarnas egna skolor och på tider som lärarna själva bestämt. Under intervjuerna riktades frågor till deltagarna på ett sådant sätt att alla fick komma till tals. Samtalen, som varade ungefär en timme, spelades in och transkriberades ordagrant. Intervjuerna genomfördes av försteförfattaren utifrån ovanstående teman och kompletterades med följdfrågor för att uppnå en tydligare bild av lärarnas laborationsundervisning.

För att få en bredare bild av fler lärares syn på laborationsundervisningen kompletterades datainsamlingen med en webbaserad enkätundersökning (se bilaga 1) och som spreds med hjälp av sociala medier och mejllistor. Totalt 66 gymnasielärare i fysik från olika delar av Sverige besvarade enkäten som omfattade 
både flervalsfrågor och långsvarsfrågor, grundade i analysarbetet från fokusgruppsintervjuerna.

\subsection{Händelselogik som analysverktyg}

Inom händelselogiken ses en handling som en logisk konsekvens av bakomliggande faktorer (Wright, 1983). I denna artikel avser handlingen lärares val av upplägg av laborationsundervisningen, och betraktas utifrån lärares beskrivningar och reflektioner. Händelselogiken kan användas för att förstå mänsklig handling i efterhandsperspektiv och kan användas för att förklara varför en person gjorde på ett visst sätt. Wright (1983) delar upp de faktorer som ligger till grund för en mänsklig handling i följande determinanter: målsättning, förmåga, plikt och möjlighet. Determinanterna kan i sin tur delas in i interna och externa determinanter. De interna determinanterna utgår från personen själv och utgörs av målsättningen med en handling och förmågan att kunna genomföra handlingen. De externa determinanterna utgår från personens omgivning och utgörs av plikter och möjligheter. Plikt är de regler och normer som en person följer. En plikt kan vara uttalad i form av en lag eller outtalad i form av en tradition. En förutsättning för att en handling ska kunna utföras är att personen har möjlighet att utföra den, till exempel kräver laborationsundervisning tillgång till laborationsmateriel.

Interna determinanter

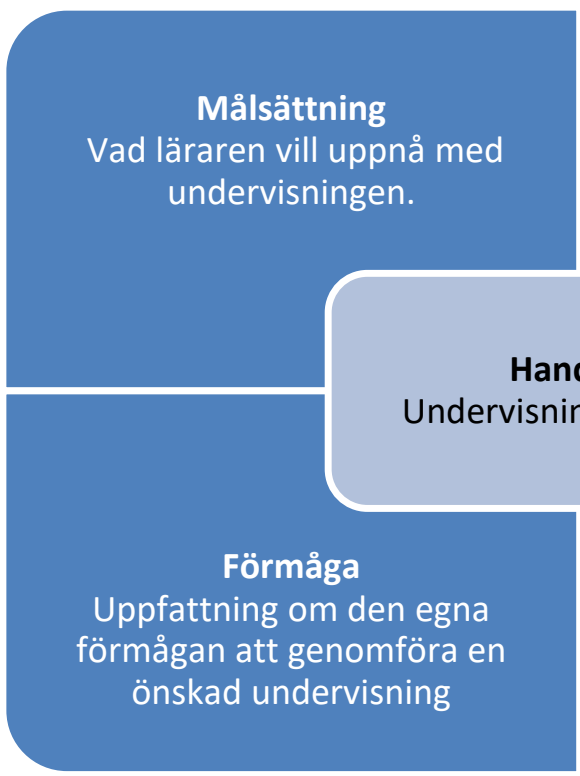

Externa determinanter

Plikt

Uppfattning om undervisningens

form och innehåll i förhållande till normer, krav och upplevda förväntningar
Handling

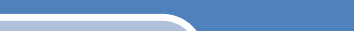

\section{s} ssituation

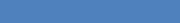

Bedömning av tillfälle, resurser och handlingsutrymme

Figur 1. Efter Lager-Nyqvist (2003). 
Händelselogikens interna determinanter, målsättning och förmåga, kan i vissa fall räcka för att förstå för en handling. Samtidigt kan det ibland vara svårt att identifiera mer än en determinant som leder fram till en handling. Om det finns flera orsaker till en handling kan den beskrivas som överbestämd, om endast en förklaring kan identifieras så erhålls en delförklaring (Wright, 1983). I denna studie söker vi både efter delförklaringar och överbestämda förklaringar till handlingen.

\subsection{Analys}

Analysen syftade till att identifiera olika faktorer som påverkar val och utformning av laborationen utifrån händelselogikens determinanter. Detta gjordes genom att kategorisera uttalanden efter lärarens målsättning, lärarens förmåga att genomföra en önskad undervisning, vilka plikter som styr laborationsundervisningen och vilka möjligheter som framträder. Flera uttalanden kunde kategoriseras under mer än en determinant. Analysprocessen växlade mellan en lodrät och vågrät analys (Thomsson, 2010). Den vågräta analysen innebar att varje intervju analyserades var för sig i syfte att identifiera teman och underteman. Därefter genomfördes den lodräta analysen, där analyserna av de olika intervjuerna jämfördes med varandra och uppkomna teman reviderades. Processen upprepades tills enhetliga teman erhölls för lärarnas handling och för händelselogikens determinanter, och dessa teman återges i avsnitt 3 . Denna process inkluderade även den ursprungliga pilotstudien.

Diskussioner kring lärarnas laborationsundervisning, både favoritlaborationer och laborationer som inte uttrycks som favoriter, har i analysen använts för att beskriva lärarnas handlingar och valet av laborationer. I de laborationer som inte beskrivs som favoritlaborationer framkommer ytterligare förklaringar till lärares val, till exempel praxis eller att en del laborationer väljs bort. Följdfrågor till studiens intervjuteman syftade till att ge en mer heltäckande bild av determinanter och handlingar som kan kopplas till den laborativa undervisningen.

\subsection{Metoddiskussion}

Tidigare tillämpning av händelselogiken som analysverktyg har kombinerat observationer med intervjuer för att kunna förstå en individs handling (LagerNyqvist, 2003; Linde, 1993). Vid ett intervjutillfälle konstrueras en motivering till en handling ofta i efterhand, oavsett om respondenten intervjuas direkt efter en handling eller om en grupp lärare får referera till sin egen undervisning. En svaghet i den här 
studien är att tiden mellan handling och motivering kan vara lång, vilket samtidigt kan anses vara en styrka genom att handlingar kan knytas till flera tillfällen och begränsas inte till ett enskilt observationstillfälle. Observationer kan visa resultatet av valet, men inte vad som ligger bakom och vad som valts bort. I denna studie fokuserar vi just på själva valet av laboration som handling. Kombinationen mellan händelselogiken och fokusgrupper ger en möjlighet att studera hur olika lärare hanterar valsituationer och hur det påverkar laborationsundervisningen, och enkätundersökningen har möjliggjort att studera hur ett större antal lärare förhöll sig till de teman som uppkom under fokusgruppsintervjuerna.

Det finns alltid en risk, oavsett metod för datainsamling, att en persons beskrivningar och åsikter kan avvika mot vad som presenteras som resultat (Robson, 2011; Stewart et al., 2007). För att validera resultaten från fokusgruppsintervjuerna erbjöds lärarna sammanfattningar av intervjuerna och några lärare kontaktades $\mathrm{i}$ efterhand för att klargöra osäkerheter. Att datainsamlingen består av en kvantitativ och kvalitativ del styrker studiens reliabilitet genom att resultaten kan trianguleras och ger samtidigt en mer komplett bild av lärarnas syn på undervisningen (Robson, 2011). Ett problem med olika metoder för datainsamling är att olika metoder kan uppvisa skillnader i resultat, men samtidigt kan skillnader öppna upp för en djupare och mer komplex förståelse för resultaten (Robson, 2011; Tracy 2010).

\section{Resultat - fokusgruppsintervjuer}

Resultaten och diskussionen i avsnitt 3 bygger på fokusgruppsintervjuerna och nedan presenteras de handlingar som kan relateras till den laborativa undervisningen som beskrevs av lärarna $\mathrm{i}$ fokusgrupperna. Handlingen presenteras först med utgångspunkt i lärarnas beskrivningar och upplägg av favoritlaborationer, och sedan till andra laborationer. Utgående från händelselogiken presenteras därefter de olika determinanter som synliggörs. Enkätundersökningen presenteras i avsnitt 4 och där utfallet jämförs med resultaten från fokusgrupperna.

\subsection{Handling - val av laborationer}

Flera av lärarnas beskrivningar av laborationer i fokusgruppsintervjuerna bygger på att låta eleverna använda bekanta samband, men också att bestämma kända konstanter. Laborationer kan också syfta till att eleven ska få bekanta sig med fenomen eller genomföra mer systematiska mätningar och beräkningar. Den 
utrustning man använder sig av kan vara enkel där eleven själv får utföra mätningar men också avancerad, till exempel genom datorstödd insamling av mätdata. Lärarnas instruktioner uppvisar olika grader av öppenhet. De favoritlaborationer som diskuteras har kategoriserats genom de faktorer som angetts ligga till grund för uppbyggnad och design: enkel utrustning, öppenhet och stationslaborationer samt datoranvändning. Avslutningsvis presenteras ett par laborationer som nämns av flera lärare, även om de av olika skäl inte är favoriter.

\subsubsection{Enkel utrustning}

Ett återkommande tema i upplägget av en favoritlaboration var enkel utrustning. Även stationslaborationerna som diskuteras nedan involverar ofta enkel materiel. Beskrivningarna av enkel materiel låter antyda mätutrustning som är mindre tekniskt avancerad, till exempel dynamometrar, vikter, tidtagarur och linjaler, men också på själva utrustningen som laborationen utgår ifrån, till exempel fjädrar, pendlar, gitter och CD/DVD skivor. Lärarnas skäl att välja enkel utrustning kan sammanfattas med:

- Enkel utrustning fungerar alltid, inget kan gå sönder och är lätt att förbereda.

"En bra laboration är en laboration som vet fungerar. Alla sakerna fungerar, det blir ett bra resultat och eleverna förstår." (Iris)

- Enkel utrustning passar för öppna laborationer.

”Vilken värmekapacitet har vatten ...//.. ingen särskild styrning.” (Hugo)

\subsection{2 Öppna laborationer och stationslaborationer}

Ett vanligt tema var "öppenhet" och omfattar oftast en till två frihetsgrader (Andersson, 1989), där problemet är givet och i viss mån även genomförandet. Läraren Gunnar på skola 2 anger att hans stationslaborationer täcker avsnitt från flera områden och antyder en viss öppenhet, då hans elever lämnas att själva bestämma vilken utrustning som ska användas och hur mätningarna ska genomföras. Flera av lärarnas exempel på öppna laborationer innehåller oftast endast en frihetsgrad, men utelämnar hypotesformulering och utvärdering. När lärarna i denna studie motiverar valet av öppna laborationer är det ingen som hänvisar till styrdokumentens ökade krav. Istället nämns att öppna laborationer tilltalar elever, väcker intresse och stärker självförtroendet. Den enda laborationsbeskrivning som inbegriper tre frihetsgrader är Lorentz beskrivning av "nedböjning av balk": 
"En inspänd balk, och den här balken brukar vara en linjal, metall eller trälinjal, det spelar ingen roll. Vad man ska mäta på det? Det är en design-labb på IB, alltså. Vad dom ska mäta på, vilket samband dom ska leta efter, är helt öppet.” (Lorentz)

\subsubsection{Datoranvändning}

Fyra av de 17 lärarna i fokusgrupperna beskriver laborationer där datorer används. Dessa laborationer baseras på simulering eller på datorstödda mätningar, ibland kombinerade med mer traditionella mätmetoder. Lärarna beskriver hur den datorstödda datainsamlingen underlättar elevens arbete med att bearbeta mätdata och att studera diagram, samtidigt är det ingen av dessa lärare som relaterar till ämnesplanens ökade krav på datoranvändning i undervisningen. Ellen är den enda som nämner simuleringar, som hon använder när hon upplever att det inte finns tillgänglig utrustning. Hon nämner också möjligheten att kunna ändra variabler som är svårare att ändra i en verklig uppställning. Ellen säger:

”Dom kan ändra variabler som dom vill. Kan vara vinkeln om det är en kastparabel."

\subsection{4 Övriga laborationer}

Den inledande frågan om favoritlaborationer var avsedd att leda in till diskussioner kring vad som utgör en bra laboration. Under intervjuerna diskuterade lärarna också många andra exempel på laborationer som ofta har ett uttalat syfte och ses som nödvändiga för att genomföra önskad undervisning. Ett vanligt syfte var att lära eleven att hantera mätutrustning, till exempel att lära ut hur ett oscilloskop fungerar. I några intervjuer framkommer laborationer som har en uttalad kultstatus eller som görs av tradition. Exempel är Kundts rör (tex Parolin \& Pezzi, 2015) och bestämningen av det jordmagnetiska fältet (tex Greenslade, 1999).

Frida: "Jordmagnetiska fältet gör man inte, för man vet ..."

Gunnar: "Jo, men det är kult."

Iris: "Den fungerar inte längre efter ombyggnaden av salen.”

Lärarna på skola 2 diskuterar laborationen "fritt fall" och jämför upplägget utifrån datorstödda mätningar och tempografen. Både Frida, Gunnar och Hugo föredrar tempografen framför datorstödda mätningar, dels genom att den tydligare kopplingen mellan mätdata och begreppet konstant acceleration, men också för att man uppfattar att den fungerar bättre för svagare elever. 
”Dom som är bäst och dom som är smartast dom fattar ju oavsett hur, dom fattar ju ändå. Men dom som har det lite jobbigt med det, dom måste nästan få sitta ner och titta, du vet, och få mäta med linjaler.” (Hugo)

\subsection{Målsettning}

\subsubsection{Färdigheter}

Flera lärare ger uttryck för en målsättning att låta eleverna använda olika färdigheter som behövs för att genomföra en laboration från början till slut: planering, hantering av utrustning, mätning, mätdatabehandling, tolkning och utvärdering och slutligen rapportskrivning. Vanligast är arbete med mätdata genom beräkningar, diagramritning, anpassning etc. Beräkningar har en framträdande roll, vilket ställs på sin spets i Gunnars uttalande kring en kombination av räkneövning och stationslaboration där beräkningsfärdigheter betonas:

”Då har jag en fem räkneövningar, fast jag kallar dom laborationer." (Gunnar)

Davids favoritlaboration med studier av impulslagen på luftkuddebana involverar datorstödd mätutrustning. Han låter sina elever träna på att framställa tabeller och rita diagram med hjälp av programvara på en dator. En förklaring till varför David låter sina elever utveckla sina färdigheter med hjälp av datorn kan förklaras Davids positiva inställning till datoranvändning. David säger, nästan urskuldande:

"Jag gillar det. Det blir nästan för mycket ibland."

\subsubsection{Förståelse}

Ett annat tema avser förståelse, framförallt för samband och fenomen men också för ett naturvetenskapligt arbetssätt. Flera lärare använder uttrycket "koppla teori till praktik", men fortsatta diskussioner visar att detta avser att tillämpa teoretiska kunskaper i ett praktiskt sammanhang. Till förståelsen bidrar också att kunna relatera laborationen till företeelser i elevens vardag. Ett par lärare beskriver hur en laboration kan ge eleven tillfälle att reflektera och diskutera sina resultat. Därigenom uppnås en ökad förståelse och ett tillfälle att koppla ihop och reflektera, över såväl teoretiska, som praktiska kunskaper från olika delområden. Till exempel Frida säger:

"Men någon annan som är bra är den där med ringklockan. Fast då har man ju ganska mycket teori bakom sig. Labben kräver mycket förberedelse och eleverna måste verkligen veta hur man ställer upp utrustningen för att allt ska fungera." 


\subsubsection{Stimulera intresse och aktivitet}

Önskan att stimulera intresse och aktivitet framkommer särskilt tydligt genom att lärarna beskriver laborationer som de uppfattar att eleverna tycker är roliga. Exempel som framkommer är öppna laborationer där lärare uppfattar att elever uppskattar ett självständigt och upptäckande arbetssätt, men också stationslaborationer som har omväxlande karaktär och som engagerar elever, till exempel: "Det blir lite fart i klassrummet" (Iris). Samtidigt uttrycker en del lärare att vissa faktorer är viktiga för att behålla elevernas förtroende för laborationen, att utrustningen ska fungera och att laborationen ger ett bra resultat. Ett bra resultat avser värdet på erhållna konstanter eller formlers överensstämmelse. Hugo uttrycker det som:

"Det måste bli hyfsat bra [resultat] i varje fall. Annars tappar eleverna förtroendet för laborationen."

\subsection{Förmåga}

De uttalanden som kan relateras till den egna förmågan uppkommer ofta kring de hinder som lärarna uppfattar med undervisningen. Det vanligaste temat om den egna förmågan var förmåga att genomföra en önskad undervisning. Här ingår också förmågan att motivera elever. Några av lärarna i studien är relativt nya på sin skola och uttrycker att de inte har inte har fullständig kännedom om skolans laborationsmateriel och att de därför förlitar sig på mer rutinerade lärare.

"Min kollega Jens har jobbat längre som lärare än mig. Ibland har han tänkt ut laborationer som han har ställt upp och som jag kan använda.” (Frida)

Flera av lärarna uttrycker en frustration kring elevers ointresse för laborationen, vilket relateras till förmågan att motivera elever. De upplever att det kan vara svårt att motivera det arbetssätt som en laboration kan innebära, till exempel att öppna laborationer medför ett annat arbetssätt än vad eleverna är vana vid. Iris säger:

"Man tappar deras intresse redan i tidigt skede för att dom kanske inte gillar öppna laborationer, eller inte har accepterat det." 


\subsection{Plikt: Normer och styrning}

Utsagor som på något sätt indikerar en styrning av laborationsundervisningen eller ett visst förhållningssätt till laborationer, har placerats under normer och styrning. Determinanten plikt spänner mellan olika yttre påverkansfaktorer, där lokal praxis blandas med starka traditioner i fysikundervisningen, samtidigt som lärarnas undervisning ytterst styrs av fysikämnets styrdokument. De teman som uppkom härunder var styrdokument och bedömning, praxis och tradition, läromedel, och styrning på skolnivå.

\subsubsection{Styrdokument och bedömning}

Den styrning som är knuten till temat styrdokument uppkommer främst i samtalsämnen kring nya kurser och bedömning, och kan kopplas till hinder eller möjligheter i undervisningen (se även 3.5). Ofta handlar det om kursmoment som antingen har tagits bort eller lagts till i både fysik- och matematikkurserna och hur lärarna har fått anpassa sin undervisning efter reformen. Carl beskriver att han upplever att uppläggen på de nya kursplanerna i matematik har medfört att hans elever inte har haft tillräcklig matematisk kunskap för att kunna genomföra en del laborationer. Det har fătt honom att kasta om ordningen på upplägget på en laboration från att tillämpa trigonometriska samband till att lära ut dito samband.

"Innan har man tänkt så här tvärtom att man vill ha det matematiskt först och sen så tillämpade man det i fysikundervisningen. Men det funkade faktiskt jättebra, att göra det praktiskt direkt.” (Carl)

De flesta lärarna bedömer sina elevers laborationsrapporter, och Frida och Hugo på skola 2 som beskriver också hur de låter sina elever sätta sig in i betygskriterierna för att lära dem hur en laborationsrapport ska se ut. Frida säger:

" Utifrån bedömningsmatrisen så ska dom verkligen sätta sig in i kriterierna."

\subsubsection{Praxis och tradition}

Praxis uttrycks ofta genom hänvisning till laborationer som läraren brukar göra, samtidigt kan den enskilde lärarens praxis skilja från de övriga kollegorna. Vissa laborationer antyder en tradition i laborationsundervisningen, se avsnitt 3.1.4, och många laborationer återanvänds år efter år. Betydelsen av skolpraxis blir tydlig för 
Hugo som nyligen har bytt skola och konstaterar att såväl utrustning som synen på utrustning och laborationer kan skilja mellan skolor.

"Några utav dom gamla labbarna som vi körde på min gamla skola finns inte här." (Hugo)

I intervjuerna diskuterar lärarna bedömningen av laborationsrapporter (se 3.4.1). Formen för bedömning skiljer sig mellan de olika skolorna, men också mellan olika lärare på samma skola. Skola 1 har utarbetat en gemensam mall för laborationsrapporter som Bertil kommenterar så här:

"Vi har tittat på en labbrapportmall, den ni gjorde förra året. Den följer egentligen gamla klassiska regler"

och antyder att det finns en stark tradition i rapportskrivningen.

\subsubsection{Läromedel}

En ytterligare faktor som berör en styrning av laborationsundervisningen är läromedel. På både skola 1 och 2 har man olika läromedel på teknik- och naturvetenskapsprogrammet. Även om man gör samma laborationer på båda programmen så styr läromedlens uppläggning i vilken ordning olika laborationer utförs:

"Vi har parallella klasser, men vi har inte samma böcker. Då kan man inte dra samma nytta av det, för då har vi plockat undan grejorna kanske." (Gunnar)

\subsubsection{Styrning på skolnivå}

Lärarnas tjänstefördelning och schemaläggning innebär en styrning på skolnivå. Under intervjun på skola 2 beskrivs hur laborationspassens längd kan påverka upplägget, till exempel Hugo, som upplever att längden på hans schemalagda laborationspass förhindrar honom att låta sina elever genomföra öppna laborationer:

Håkan: "Vi har sextio minuters labbar på fysik 1 nu."

Gunnar: "Jag har nittio."

Frida: "Jag har faktiskt nittio."

Håkan: "Ja, det är bättre. Men sextio är alldeles för lite."

Frida: "Mm, det är det."

Håkan: "Om man ska ha en öppen labb." 


\subsection{Möjlighet och hinder}

Kring determinanten möjlighet gavs exempel på både möjligheter och på hinder som avsaknad av möjligheter. Bland faktorer kopplade till möjlighet och hinder finns underteman som: eleven - med intresse, förståelse och förkunskaper och kontext såsom arbetsmiljö, schema, utrustning och stöd.

\subsubsection{Eleven}

Lärarna ger exempel på hur laborationer engagerar elever i olika grad och hur vissa laborationer fungerar bättre i vissa elevgrupper. Några lärare beskriver hur elever uppvisar ett ointresse gentemot laborationen vilket Iris upplever som ett särskilt problem vid öppna laborationer. Hon förklarar detta med att eleverna inte är vana vid öppna laborationer. Både Gunnar och Lorentz poängterar att elever måste vänjas vid öppna laborationer, dels genom att eleverna måste ha tillräcklig teoretisk kunskap men också kännedom om tillgänglig laborationsmateriel. Till exempel säger Lorentz:

"Så man kan ju inte ta det [öppna laborationer] för tidigt heller."

Trots att lärarna anpassar sin laborationsundervisning efter elevernas kunskap uttrycker några en frustration över elevernas förkunskaper. Vid diskussioner på skola 1 poängteras bristande förkunskaper hos eleven som inbegriper både matematik och fysik. En förklaring till elevers minskade praktiska vana förklarar tre av lärarna med en förändrad livsstil hos dagens ungdom.

"Jag tänkte på teknikeleverna från tidigare nittitalet, dom körde ofta moped. Då var det lätt att kunna hänvisa till tändstift. Det är inte många idag man kan diskutera det med." (Carl)

\subsubsection{Kontext}

Temat kontext beskriver det sammanhang och den situation som undervisningen bedrivs i. Alla lärarna ger uttryck för stress över sin egen arbetssituation vilket resulterar i att man inte hinner genomföra eller utveckla undervisningen som man önskar. Hugos sextio-minuters laborationer (avsnitt 3.4.4), förhindrar honom att göra öppna laborationer och ger upphov till stress. En annan faktor som påverkar Davids laborationsundervisning är att laborationspass ofta försvinner och att detta gör det svårt att genomföra laborationer på moment som ligger i slutet på kurserna: 
"Man hinner sällan göra någon laboration på det som ligger mot slutet av kursen." (David)

Lärarna på skola 2 uttrycker en frustration över laborationsmateriel som inte fungerar och att man inte har tid att felsöka och reparera, och avsaknaden av institutionstekniker. Dessutom upplever de att man tappar elevens intresse om laborationen inte fungerar. Istället väljer man enklare utrustning, ofta i form av stationslaborationer, vilket på så sätt även minskar förberedelsetiden:

Iris: ”Då är stationslabbar ibland bra då. Om man hittar dom här som är enkla.

Som inte behöver så mycket utrustning."

Gunnar: "Det var så det började egentligen. Att man gjorde stationslabbarna, för att dom var smidiga."

\section{Den utökade studien}

Enkätundersökningen genomfördes efter en noggrann analys av intervjuerna. Analysen av fokusgruppsintervjuerna låg till grund för enkätfrågornas utformning (se bilaga 1) och enkäten skickades ut till ett större antal lärare över hela Sverige. I det här avsnittet presenteras utfallet från enkätundersökningen och jämförs med resultatet från fokusgruppsintervjuerna.

\subsection{Resultat och jämförelse med fokusgruppsintervjuerna}

I en av enkätfrågorna ombads lärare välja ut tre faktorer från 14 alternativ som de ansåg vara viktigast i deras planering av laborationsundervisningen, och där de olika svarsalternativen kan kopplas till händelselogikens determinanter. 


\section{Fråga 4}

Vilka faktorer är viktigast i det val av laborationer? Välj tre alternativ

Att jag väljer laborationer där jag vet att utrustningen fungerar Att jag gör laborationer som jag brukar göra

Att laborationen ger ett bra resultat

Att eleven tycker att laborationen är rolig

Att laborationen bygger på enkel utrustning, för det underlättar min förberedelse

Att laborationen bygger på enkel utrustning, för då blir det enklare för eleven att förstå vad de ska göra

Att jag gör samma laborationer som mina kollegor

Att eleverna får träning i att planera en undersökning

Att eleverna får träning $\mathrm{i}$ att analysera resultat och hitta samband

Att laborationen illustrerar begrepp som diskuteras i boken

Att eleverna får förståelse för ett experiment som spelat roll i fysikhistorien

Att eleverna kan visa att de uppnått något eller några av målen $\mathrm{i}$ kunskapskraven

Att laborationen bygger på datorstödd mätutrustning (eller motsvarande)

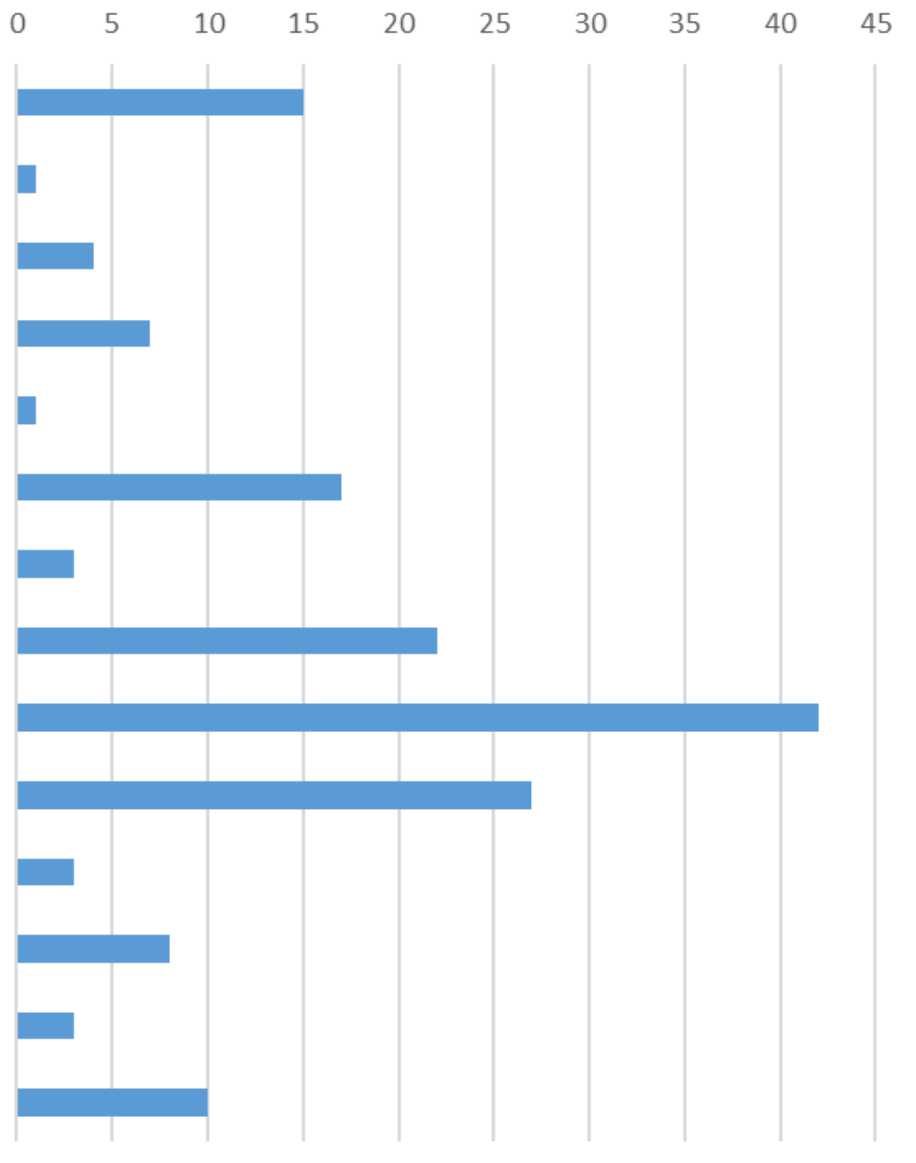

Figur 2. Utfall från fråga 4: "Vilka faktorer viktigast i ditt val av laborationer?".

De fem mest valda alternativen bland de 66 svaren var:

1. Att eleverna făr träning i att analysera resultat och hitta samband (42 st)

2. Att laborationen illustrerar begrepp som diskuteras i boken (27 st)

3. Att eleverna făr träning i att planera en undersökning (22 st)

4. Att laborationen bygger på enkel utrustning, för då blir det enklare för eleven att förstå vad de ska göra (17 st)

5. Att jag väljer laborationer där jag vet att utrustningen fungerar (15 st)

Utfallet på alternativ 1, 2 och 3 ovan kan relateras till resultatet från fokusgrupperna, där vanliga målsättningar syftade till en ökad förståelse och en träning av färdigheter. Lärarna hade i enkätundersökningen även en möjlighet att ange egna alternativ. Även dessa övriga svar kan i stort kopplas ihop med förståelsen och med en utveckling av praktiska färdigheter. En lärare skriver till exempel: 
"Att eleverna får labbvana."

Utfallet på alternativ 4 och 5 kan kopplas till resultatet att flera av lärarna i fokusgrupperna uppskattar laborationer som bygger på enkel utrustning, se avsnitt 3.1.1. Enkätundersökningen ger en ytterligare förklaring till lärares val av enkel utrustning: att enkel utrustning är lättare för eleven att använda. Vad som däremot har blivit underordnat jämfört med utfallet från fokusgruppsintervjuerna är en affektiv målsättning. Ett resultat som kan kopplas till en skillnad i perspektiv ur vilken undervisningen diskuterades: intervjuerna fokuserade konkret på lärares favoritlaborationer och enkäten efterfrågade vad som påverkar lärarnas laborationer i allmänhet.

I fokusgruppsintervjuerna framkom att "bra resultat" som en viktig faktor i lärares favoritlaborationer samt att en viktig målsättning var att "koppla ihop teori med praktik". I enkäten fick lärare markera graden av instämmande i påståendet "För mig är det viktigt att en laboration ger ett bra resultat (till exempel att $\mathrm{g}=9,82 \mathrm{~m} / \mathrm{s}^{2}$ )”.

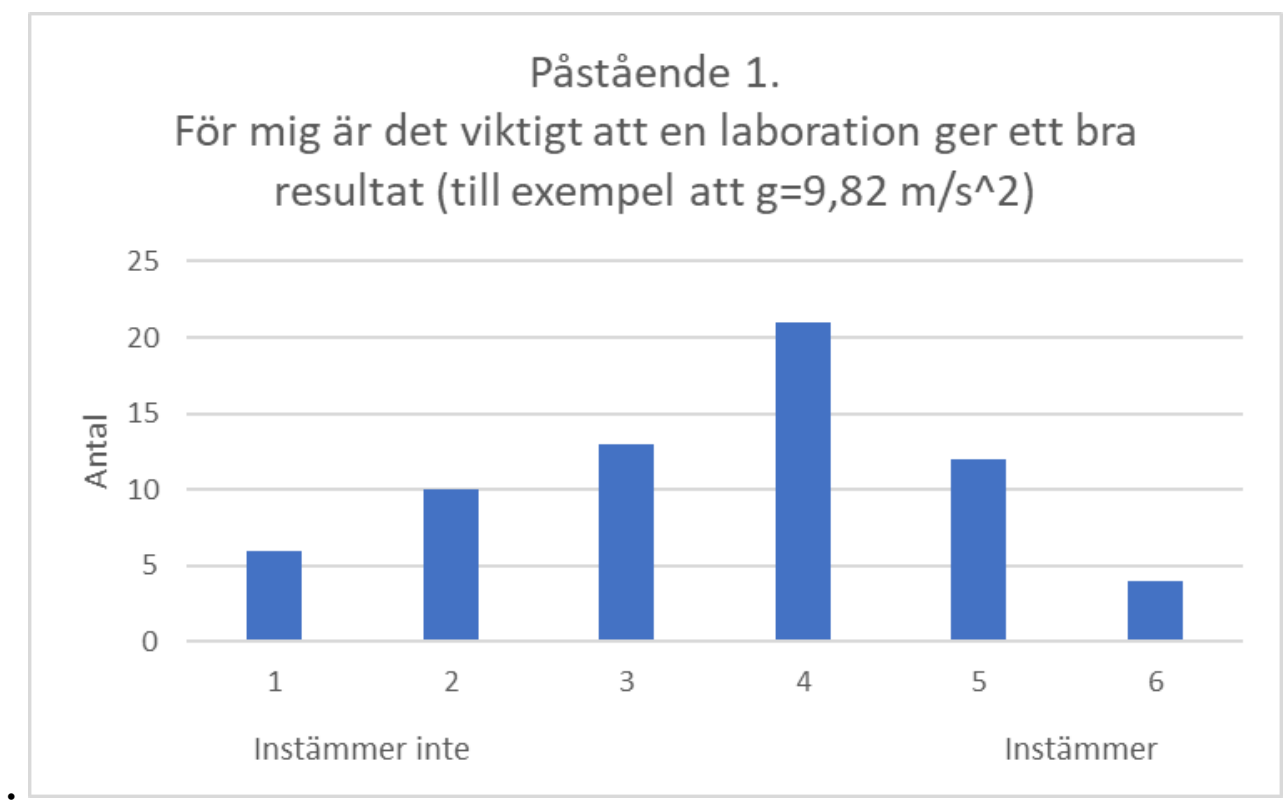

Figur 3. Utfall till påståendet: "För mig är det viktigt att en laboration ger ett bra resultat (till exempel att $\left.g=9,82 \mathrm{~m} / \mathrm{s}^{2}\right)^{\prime \prime}$.

Av 66 lärare var 37 positiva till påståendet, och majoriteten av lärarna i enkäten höll också med om att "Jag tycker att laborationsundervisningen fungerar som en bekräftelse på att den teoretiska undervisningen är sann": 


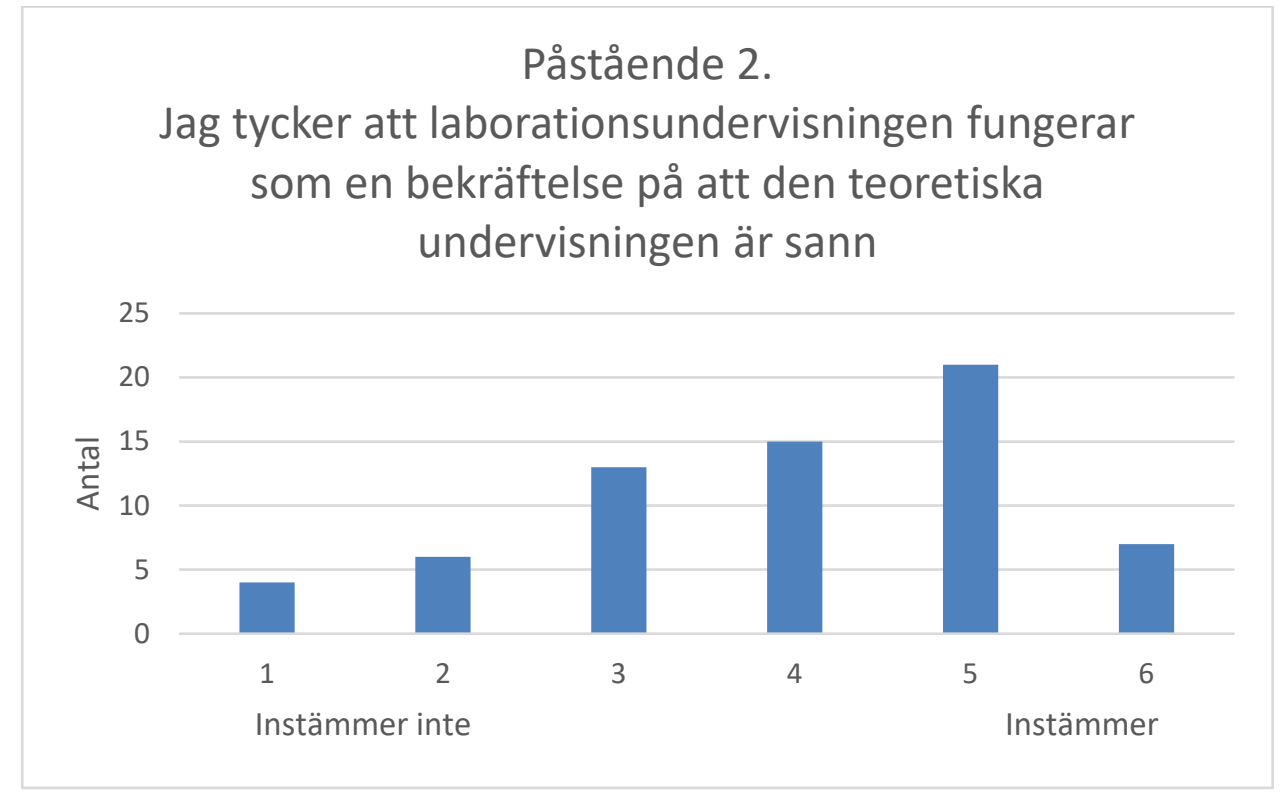

Figur 4. Utfall till påståendet: "Jag tycker att laborationsundervisningen fungerar som en bekräftelse på att den teoretiska undervisningen är sann".

Dessa resultat tyder på att en viktig och underliggande målsättning i lärarnas laborationsundervisning är att tillämpa den teoretiska undervisningen. En av respondenterna kommenterade:

"Blir bara förvirrande för eleven om det inte stämmer, i alla fall i början av kursen."

Bland övriga framkommer att andra målsättningar kan vara viktigare, till exempel att vänja eleverna vid öppna laborationer och laborationer som kan ge flera olika svar, eller att påvisa mätosäkerhet då uppmätt värde avviker från tabellvärden. En lärare skriver:

"Sann"? Ibland bekräfta, ibland rent förmågebaserad, ibland helt öppen."

Från fokusgruppsintervjuerna framstod styrdokumenten som underordnade vid planeringen av en laboration. En majoritet av respondenterna i enkätundersökningen är dock positiva till påståendet "Jag har ämnesplanens förmågor i åtanke när jag planerar en laboration": 


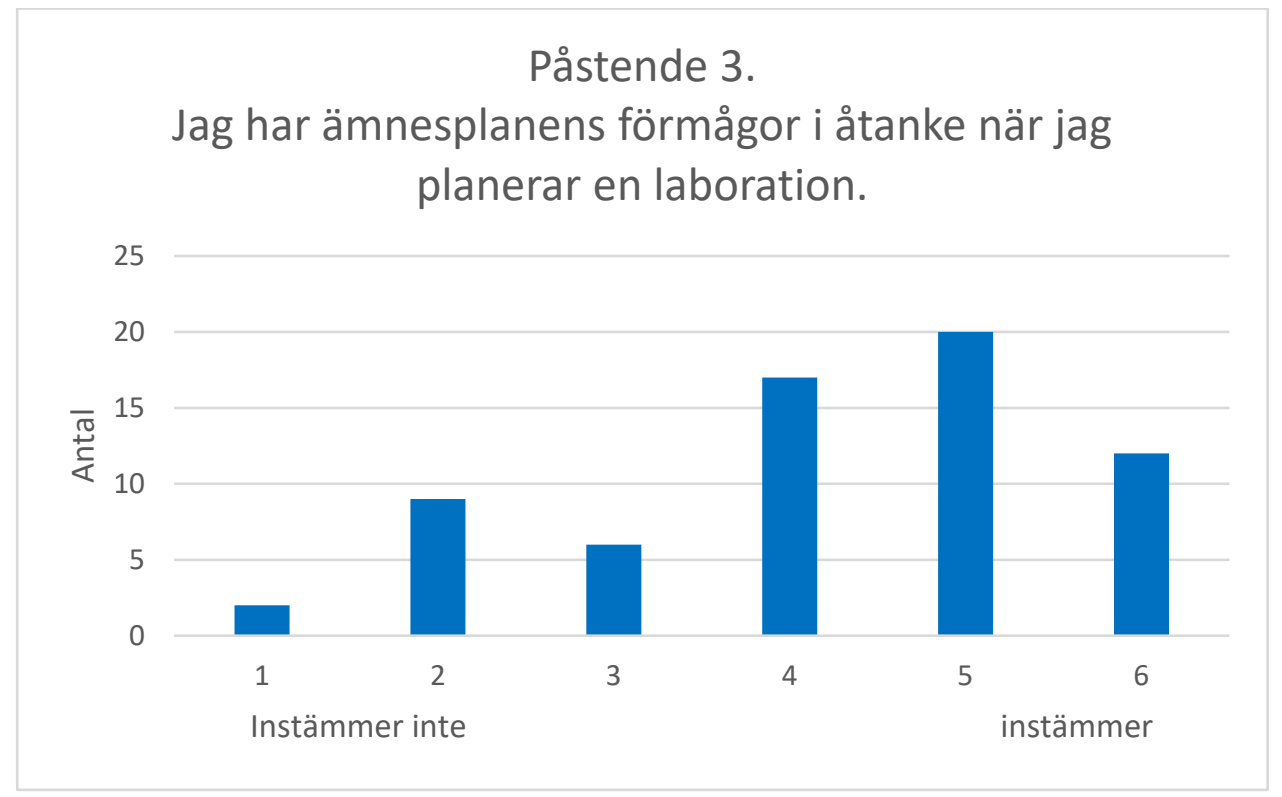

Figur 5. Utfall till påståendet: " Jag har ämnesplanens förmågor i åtanke när jag planerar en laboration".

Samtidigt visar resultaten från enkäten att det finns faktorer som anges som viktigare än ”Att eleverna kan visa att de uppnått något eller några av målen i kunskapskraven styrdokumenten". Till exempel ansågs det viktigare "Att laborationen illustrerar begrepp som diskuteras i boken" (se figur 2). Praxis och tradition framträdde som starka teman i fokusgruppsintervjuerna, men framstår som svagare i enkätundersökningen (se utfall på alternativen "Att jag gör laborationer som jag brukar göra" och "Att jag gör samma laborationer som mina kollegor" i figur 2). Däremot är en majoritet av lärarna i enkätundersökningen positivt inställda till "ett bra resultat" (se figur 3) och till att laborationsundervisningen fungerar som en bekräftelse av den teoretiska undervisningen (se figur 4), påståenden som kan kopplas till en traditionell undervisning och den praxis som är kopplad därtill (se avsnitt 1.2).

\section{Diskussion}

I denna del analyseras lärares beskrivningar av laborationsundervisningen, och jämförs med resultatet av de olika determinanterna, enkäten och med tidigare forskning. Resultaten visar bland annat att den nya ämnesplanens utökade krav på bedömning av laborativa färdigheter, inklusive planering och utvärdering, inte har fătt fullt genomslag i undervisningspraktiken vid studiens genomförande. Resultaten 
från fokusgruppsintervjuerna och enkätundersökningen visar bland annat att ett "bra resultat” och att kopplingen till den teoretiska undervisningen värderas högt av lärare.

\subsection{Val och upplägg av laborationer}

De olika kategorierna av lärarnas laborationer ger en bild av de ställningstaganden som en lärare ställs inför vid valet av en laboration. Ur resultaten framträder olika förklaringar till lärarnas val och upplägg av laborationer, förklaringar som kan kopplas till händelselogikens determinanter. Förklaringar till varför en lärare väljer en laboration återfinns ofta bland determinanterna målsättning och plikt, förklaringar som kan sammanfattas med att lärares val av upplägg styrs av det syfte som läraren vill uppnå och att valet styrs av det som läraren som uppfattar som ett "måste”. Samtidigt avspeglas en frihet i lärarens laborationsundervisning, till exempel att lärarens val påverkas av ett eget intresse (se avsnitt 3.2.1). Det framkommer också hur lärarens val av laborationer starkt styrs av praxis och av tillgången till laborativ utrustning (se avsnitt 3.4.2). Affektiva målsättningar var framträdande i lärarnas val av favoritlaborationer (se avsnitt 3.2.3), vilket leder till en risk att laborationer som eleverna inte tycker om väljs bort av läraren. Förklaringar till varför en lärare väljer bort en laboration återfinns ofta bland determinanterna förmåga och möjligheter, till exempel lärarens uppfattning om den egna förmågan (se avsnitt 3.3) och tidsbrist och trasig utrustning (se avsnitt 3.5.2). Resultaten indikerar vidare att laborationen ofta har den teoretiska undervisningen som utgångspunkt, där eleverna făr använda kända samband och bestämma värden på konstanter. Lärarna i fokusgruppsintervjuerna upplever att god överensstämmelse mellan teori och experiment är viktig för elevernas uppskattning av laborationen. I likhet med andra studier av fysiklärares syn på fysikundervisningen (Angell, Guttersrud, Henriksen, \& Isnes, 2004; Engström, 2011; Siorenta \& Jimoyiannis, 2008) lyfter lärarna i denna studie fram syftet att täcka kursinnehåll och att ge tillfälle att använda beräkningsfärdigheter. Under intervjuerna framkommer enstaka exempel på helt öppna laborationer där eleven får möjlighet till mer självständig kunskapsbildning.

\subsection{Målsättning}

Lärarnas kognitiva målsättning svarar mot en strävan till en ökad förståelse och uttrycks ofta genom att omsätta teori till praktik. Liknande resultat har erhållits i andra studier av lärare i naturvetenskapliga ämnen på högstadie-, gymnasie- och högskolenivå (Bergendahl, 2004; Högström, Ottander, \& Benckert, 2006; Ottander \& 
Grelsson, 2006; Tiberghien et al., 2001). I många av de beskrivna laborationerna ska eleverna använda kända samband eller bestämma kända konstanter. Ett "bra resultat" avseende värdet på fysikaliska konstanter eller överensstämmelse med kända samband blir då en viktig faktor för en bra laboration och implicerar att laborationen ofta har en verifierande funktion. Vid en jämförelse av nyare ämnesplanerna i fysik (Skolverket, 2011a) och de föregående kursplanerna (Skolverket, 2000) framträder att laborativa färdigheter, som att formulera en hypotes, planera en laboration och utvärdera resultaten, har fått en mer framträdande roll. Ett sätt att tillgodose dessa ökade krav är låta eleverna göra laborationer som bygger på en eller flera frihetsgrader. Flera av lärarnas exempel på öppna laborationer innehåller oftast endast en frihetsgrad, men utelämnar hypotesformulering och utvärdering. När lärarna i denna studie motiverar valet av öppna laborationer är det ingen som hänvisar till styrdokumentens ökade krav. Istället nämns att öppna laborationer tilltalar elever, väcker intresse och stärker självförtroendet. Affektiva målsättningar framstår som starka påverkansfaktorer i lärares val och upplägg av laborationsundervisningen, till exempel genom att läraren väljer laborationer som eleverna tycker om, och laborationer som uppfattas öka elevens självförtroende (se 3.2.3). Lärarna anger inga motiveringar till sina affektiva mål, trots att ett av målen i läroplanen är att läraren ska: "stärka varje elevs självförtroende samt vilja och förmåga att lära" (Skolverket, 2011b, s 10). Att lärare vill att undervisningen ska uppfattas som lustfylld kan höra samman med en önskan att vara omtyckt som lärare (jfr Wright, 1983) eller att läraren själv har negativa upplevelser från sin egen skolgång som man inte vill ge eleverna (Lager-Nyqvist, 2003). Affektiva målsättningar var framträdande i fokusgrupperna, men var mindre framträdande i enkätundersökningen. Denna skillnad framkom även i studie på svenska högstadielärare (Högström et al., 2006), där affektiva målsättningar var starkare i lärarnas beskrivningar av specifika laborationer än när laborationsundervisningen diskuteras allmänt.

\subsection{Förmåga}

Lärarens uppfattning om sin egen förmåga kan ha en hämmande effekt på handlingen, men förmågor kan också förvärvas och utvecklas (Wright, 1983), till exempel genom utbildning eller kompetensutveckling. Utvecklingen av den egna förmågan diskuteras i samband med kollegialt samarbete när mindre rutinerade kollegor förlitar sig på äldre kollegor. Yngre lärare utvecklar sin förmåga genom att 
delta i praktiken som ett slags lärlingar för att succesivt bli mer rutinerade lärare (Lave \& Wenger, 1991). Bristen på tid gör samtidigt att man inte hinner utveckla eller bedriva den undervisning man vill. Endast en lärare i fokusgrupperna nämner en laboration som tar en utgångspunkt i experimentella resultat för att eleverna självständigt ska kunna dra teoretiska slutsatser. Här avses Lorentz beskrivning av nedböjning av en linjal och han benämner den som en IB-laboration. Fysikundervisningen på IB följer en annan kursplan än den svenska gymnasiekursen. Att laborationsundervisningen har en starkare ställning på IB och att IB-lärare erbjuds kontinuerlig fortbildning (jfr. IBO, 2018) kan ha främjat Lorentz förmåga att bedriva laborativ undervisning samt påverkat Lorentz syn på vad som är en bra laboration.

\subsection{Plikt}

Styrdokument ger i fokusgrupperna huvudsakligen upphov till diskussioner rörande betygskriterierna i samband med bedömning. Från intervjuerna framkommer uttalanden kring de lärandemålen som återfinns i ämnesplanen i liten utsträckning. Även om de flesta lärarna bedömer sina elevers laborationsrapporterrapporter så finns en skillnad i hur och vad man bedömer, vilket kan förklaras med att olika lärare tolkar ämnesplanen olika (Engström, 2011). En annan förklaring till varför lärare utvecklar olika bedömningspraktiker är frånvaron av tillräckligt bedömningsstöd (Yung, 2001). Resultaten visar att Skolverkets bedömningsstöd inte alltid når ut till lärarna. Praxis kan föras vidare genom att lärare reproducerar sin egen utbildning med underliggande synsätt (Engström, 2011). I vårt material ser vi ett exempel på hur metoder förs vidare när Gunnars beskriver hur han ofta låter sina elever sålla bland befintlig materiel och arbeta under liten styrning (se avsnitt 3.1.2). En annan del av praxis som framkommer, här liksom i tidigare studier (Engström, 2011; Tiberghien et al., 2001) är att knyta ihop laborationsundervisningen med matematik $\neg$ undervisningen och en betoning på beräkningsfärdigheter. I likhet med tidigare studier (Berg, 2013; Holmström et al., 2018) tyder resultaten på en stark tradition i laborationsundervisningen. 


\subsection{Möjligheter}

Från fokusgrupperna framträder en pressad bild av undervisningen vilket avspeglas i att fler hinder än möjligheter beskrivs. Tidsbrist och stress är återkommande hinder och som gör att lärarna får bortprioritera element som uppfattas som tidsödande eller som inte är obligatoriska. Istället fokuserar man på att praktiska detaljer som till exempel att slutföra kursen innan kurstiden är slut eller att man väljer bort utrustning och laborationer som inte fungerar tillförlitligt. Att utrustning och laborationer inte fungerar pekar på behovet av felsökning och underhåll av materiel, och kan kopplas bristen på tillgång till institutionstekniker, vilket lärarna på skola 2 uttrycker att de saknar.

Studien genomfördes under vad som kan beskrivas som implementeringsfasen av en ny läroplan (GY11) för gymnasiet, med nya ämnesplaner i alla ämnen och ett nytt betygssystem. För fysik innebär Gy11 bland annat ökade krav på laborativa förmågor, inklusive planering och analys. I fokusgruppsintervjuerna är det dock andra jämförelser som blir tydligare. Lärarna reflekterar över elevernas praktiska handhavande av utrustning, och över förändrade matematikkunskaper, som delvis kan hänföras till minskad styrning av gymnasieprogrammens uppläggning och ordning mellan kurserna. Enkätundersökningen tyder på en större medvetenhet gentemot den nya ämnesplanen. Resultaten från fokusgruppsintervjuerna och enkätundersökningen indikerar dock att styrdokumenten inte är den viktigaste faktorn när en lärare väljer en laboration, och illustrerar att det tar tid innan ämnesreformer når fullt genomslag i lärares praktik (jfr Skolverket, 2004).

\section{Sammanfattning och slutsatser}

I studien karaktäriseras lärarnas favoritlaborationer utifrån olika upplägg: enkel utrustning, öppna laborationer och stationslaborationer, samt datoranvändning. Det framkommer också mer övergripande teman i dessa laborationer, teman som ligger till grund för lärares syn på favoritlaborationer och val av laborationer; dels att laborationen ger "ett bra resultat" och att läraren önskar koppla ihop "teori med praktik", som indikerar att den teoretiska undervisningen ligger till grund för laborationen, dels laborationer som eleverna tycker om att göra. Dessa upplägg och teman kan i sin tur avspegla hur olika faktorer påverkar lärares laborationsundervisning. Händelselogikens determinanter har fungerat som ett verktyg i analysen i hur olika faktorer påverkar lärares laborationsundervisning, 
faktorer som leder till att läraren väljer eller väljer bort en viss laboration. Att lärare till exempel väljer datorstödd mätutrustning i undervisningen kan kopplas till ett personligt intresse, snarare än att möta ämnesplanens ökade krav. Kontextuella ställningstaganden, till exempel fungerande utrustning och praxis, framstår som starkare påverkansfaktorer än styrdokumenten. Betydelsen av skolpraxis blir tydlig för de lärare som bytt skola och ämnespraxis speglas i en tradition som förs vidare från äldre lärare till yngre.

Studien ger insyn i hur lärare väljer laborationer och hur olika faktorer påverkar lärares laborationsundervisning, den ger insikt i ämnesplanens implementering och ger kunskap som till exempel kan användas i lärarutbildningen. Resultaten tyder på att implementeringen av den nya ämnesplanen tar tid, och att andra faktorer spelar större roll för lärares val av laborationer. Enligt Tiberghien et al. (2001) finns det få studier som analyserar lärares praktik, ett område som denna studie ger ett bidrag till, även om fokus i den här studien är lärares beskrivning av sin praktik. Lika viktigt som det är att förstå hur en reform har fungerat genom att studera elevens lärande och betyg, lika viktigt är det att söka förståelse för hur lärares undervisning kan bidra (Stigler \& Hiebert, 2009). Laborationsundervisningen ger värdefulla tillfällen för lärande, men resultaten tyder på att dessa tillfällen kan påverkas negativt (se även Holmström et al., 2018). Laborationsundervisningen behöver en ökad status som motverkar negativa kontextuella faktorer och lärare behöver implementeringsstöd som sträcker sig över en längre tid. Studien visar på ett fortsatt behov av forskning kopplad till gymnasial laborationsundervisning i fysik.

\section{Referenser}

Andersson, B. (1989). Grundskolans naturvetenskap: Forskningsresultat och nya idéer / Björn Andersson Stockholm: Utbildningsförl., 1989; (Borås: Centraltr.); 1. uppl.

Angell, C., Guttersrud, Ø, Henriksen, E. K., \& Isnes, A. (2004). Physics: Frightful, but fun. pupils' and teachers' views of physics and physics teaching. Science Education, 88(5), 683-706. https://doi.org/10.1002/sce.10141

Bergendahl, C. (2004). Development of competence in biochemical experimental work: Assessment of complex learning at university level / Christina Bergendahl Umeå: Dept. of Chemistry, Univ., 2004 (Umeå: Solfjädern).

Engström, S. (2011). Att vördsamt värdesätta eller tryggt trotsa: Gymnasiefysiken, undervisningstraditioner och fysiklärares olika strategier för energiundervisning (Doctoral dissertation, Mälardalen University).

Gott, R., \& Duggan, S. (2002). Problems with the assessment of performance in practical science: Which way now? Cambridge Journal of Education, 32(2), 183-201. 
Greenslade, T. (1999). Examination questions based on historical apparatus. The Physics Teacher, 37 .

Grettve, A., Israelsson, M., \& Jönsson, A. (2014). Att bedöma och sätta betyg: Tio utmaningar i lärarens vardag. Natur och kultur.

Holmes, N. G., \& Wieman, C. E. (2016). Examining and contrasting the cognitive activities engaged in undergraduate research experiences and lab courses. Physical Review Physics Education Research, 12(2), 020103. https://doi.org/10.1103/PhysRevPhysEducRes.12.020103

Holmström, S., Pendrill, A.-M., Reistad, N., \& Eriksson, U. (2018). Gymnasiets laborationsundervisning i fysik - mellan tradition och ändrade styrdokument. LUMAT: International Journal on Math, Science and Technology Education, 6(1), 1-21. Hämtad från https://www.lumat.fi/index.php/lumat/article/view/220

Högström, P., Ottander, C., \& Benckert, S. (2006). Lärares mål med laborativt arbete: Utveckla förståelse och intresse. Nordina, 5, 54-66.

IBO (2014). Physics guide. Hämtad 2018-10-26 från https://ibphysicsnotes.files.wordpress.com/2016/o1/ib-physics-syllabus.pdf

IBO (2018). International Baccalaureate. Hämtad från 2018-10-26 från www.ibo.org.

Kvale, S., Brinkmann, S., \& Torhell, S. (2009). Den kvalitativa forskningsintervjun / Steinar Kvale, Svend Brinkmann; översättning: Sven-Erik Torhell Lund: Studentlitteratur, 2009 (Ungern); 2. uppl.

Kirschner, P. A., Sweller, J., \& Clark, R. E. (2006). Why minimal guidance during instruction does not work: An analysis of the failure of constructivist, discovery, problem-based, experiential, and inquiry-based teaching. Educational psychologist, 41(2), 75-86. https://doi.org/10.1207/s15326985ep4102_1

Lager-Nyqvist, L. (2003). Att göra det man kan: En longitudinell studie av hur sju lärarstudenter utvecklar sin undervisning och formar sin lärarroll i naturvetenskap / Lotta Lager-Nyqvist Göteborg: Acta Universitatis Gothoburgensis, 2003.

Lave, J., \& Wenger, E. (1991). Situated learning: Legitimate peripheral participation. Cambridge university press.

Linde, G. (1993). On curriculum transformation: Explaining selection of content in teaching. Stockholm: HLS (Högsk. för lärarutbildning).

Lunetta, V. N., Hofstein, A., \& Clough, M. P. (2007). Learning and teaching in the school science laboratory: An analysis of research, theory, and practice. Handbook of Research on Science Education, 393-441.

Meltzer, D. E., \& Otero, V. K. (2015). A brief history of physics education in the United States. American Journal of Physics, 83(5), 447-458. https://doi.org/10.1119/1.4902397

Meltzer, D. E., \& Thornton, R. K. (2012). Resource letter ALIP-1: active-learning instruction in physics. American journal of physics, 80(6), 478-496. DOI: 10.1119/1.3678299

Millar, R., Tiberghien, A., \& Le Maréchal, J. (2002). Varieties of labwork: A way of profiling labwork tasks. In D. Psillos, \& H. Niedderer (Eds.), Teaching and learning in the science laboratory (pp. 9-20) Springer.

Osborne, J. (2015). Practical work in science: Misunderstood and badly used? School Science Review, 96(357), 16-24.

Ottander, C., \& Grelsson, G. (2006). Laboratory work: The teachers' perspective. Journal of Biological Education (Society of Biology), 40(3), 113-118.

https://doi.org/10.1080/00219266.2006.9656027

Parolin, S. O., \& Pezzi, G. (2015). Kundt's tube experiment using smartphones. Physics Education, 50(4), 443. http://dx.doi.org/10.1088/0031-9120/50/4/443 
Robson, C. (2011). Real world research: A resource for users of social research methods in applied settings (3. ed.). Chichester: Wiley.

Siorenta, A., \& Jimoyiannis, A. (2008). Physics instruction in secondary schools: An investigation of teachers' beliefs towards physics laboratory and ICT. Research in Science \& Technological Education, 26(2), 185-202. https://doi.org/10.1080/02635140802037328

Skolverket. (2000). Kursplan för fysik. Hämtad 2018-10-26 från https://www.skolverket.se/undervisning/gymnasieskolan/laroplan-program-och-amnen-igymnasieskolan/hitta-tidigare-amnen-och-kurser-ar-2000-2011-i-

gymnasieskolan?url=1530314731\%2Fsyllabuscw\%2Fjsp\%2FsubjectKursinfo.htm\%3Fsubjec tCode\%3DFY2000\%26courseCode\%3DFY1201\%26lang\%3Dsv\%26tos\%3Dgy20oo\&sv.url= 12.5dfee44715d35a5cdfaa4bo\#anchor_FY1201

Skolverket. (2004). Nationella utvärderingen av grundskolan 2003: Sammanfattande huvudrapport. Stockholm: Statens skolverk.

Skolverket. (2011a). Ämnesplan i fysik. Hämtad 2018-10-26 från https://www.skolverket.se/undervisning/gymnasieskolan/laroplan-program-och-amnen-igymnasieskolan/gymnasieprogrammen/amne?url=1530314731\%2Fsyllabuscw\%2Fjsp\%2Fs ubject.htm\%3FsubjectCode\%3DFYS\%26lang\%3Dsv\%26tos\%3Dgy\&sv.url=12.5dfee44715d3 5a5cdfa92a3

Skolverket. (2011b). Läroplan, examensmål och gymnasiegemensamma ämnen för gymnasieskola 2011.

Skolverket. (2018a). Bedömningsportalen i fysik. Hämtad 2018-o8-o6 från

https://bp.skolverket.se/web/bs_gy_fys/start

Skolverket. (2018b). Läroplaner, ämnen \& kurser. Hämtad 2018-10-26 från

https://www.skolverket.se/undervisning/gymnasieskolan/laroplan-program-och-amnen-igymnasieskolan/gymnasieprogrammen/amne?url=1530314731\%2Fsyllabuscw\%2Fjsp\%2Fs ubject.htm\%3FsubjectCode\%3DMAT\%26lang\%3Dsv\%26tos\%3Dgy\&sv.url=12.5dfee44715d 35a5cdfa92a3

Stewart, D. W., Shamdasani, P. N., \& Rook, D. W. (2007). Focus groups: Theory and practice (2. uppl. ed.). Thousand Oaks, Calif.: Sage Publications.

Stigler, J. W., \& Hiebert, J. (2009). The teaching gap: Best ideas from the world's teachers for improving education in the classroom (1st Free Press trade pbk. ed. ed.). New York: Free Press.

Thomsson, H. (2010). Reflexiva intervjuer / Heléne Thomsson Lund: Studentlitteratur, 2010 (Malmö: Holmbergs i Malmö); 2. uppl.

Tiberghien, A., Veillard, L., Le Maréchal, J., Buty, C., \& Millar, R. (2001). An analysis of labwork tasks used in science teaching at upper secondary school and university levels in several european countries. Science Education, 85(5), 483-508. doi:10.1002/sce.1020

Tracy, S. J. (2010). Qualitative quality: Eight "big-tent” criteria for excellent qualitative research. Qualitative inquiry, 16(10), 837-851.

van den Berg, E. (2013). The PCK of laboratory teaching: Turning manipulation of equipment into manipulation of ideas. Scientia in Educatione, 4(2), 74-92.

Wellington, J. J. (1998). Practical work in school science. time for re-appraisal. In J. J. Wellington (Ed.), Practical work in school science which way now? (pp. 3-15) London; New York: Routledge, 1998.

Wright, G. H. v. (1983). Philosophical papers of Georg Henrik von Wright. vol. 1, practical reason. Oxford: Blackwell. 
Yung, B. H. W. (2001). Three views of fairness in a school-based assessment scheme of practical work in biology. International Journal of Science Education, 23(10), 985-1005. doi:10.1080/09500690010017129 


\section{Bilaga 1. Enkät - Laborationsundervisningen på gymnasiet}

Syftet med denna enkät är att ge en insikt i lärares åsikter kring laborationsundervisningen. Undersökningen kommer att användas i forskningssyfte och alla svar är anonyma.

*Obligatorisk

1. För mig är det viktigt att en laboration ger ett bra resultat (till exempel att $g=9,82 \mathrm{~m} / \mathrm{s}^{\wedge} 2$ ).

* Markera endast en oval.

Instämmer inte alls $\bigcirc \bigcirc \bigcirc^{1} \bigcirc \bigcirc$

Kommentar (frivilligt)

2. Jag tycker att laborationsundervisningen fungerar som en bekräftelse på att den teoretiska undervisningen är sann.

* Markera endast en oval.

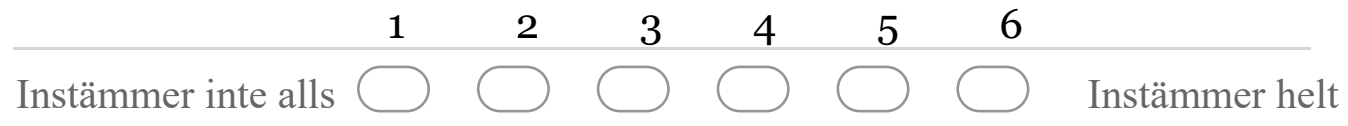

Kommentar (frivilligt)

3. Jag har ämnesplanens förmågor i åtanke när jag planerar en laboration

* Markera endast en oval.

Instämmer inte alls $\bigcirc \bigcirc \bigcirc \bigcirc$

Kommentar (frivilligt) 
4. Vilka faktorer är viktigast $\mathrm{i}$ ditt val av laborationer? Välj tre alternativ * Markera alla som gäller.

Att jag väljer laborationer där jag vet att utrustningen fungerar

Att jag gör laborationer som jag brukar göra

Att laborationen ger ett bra resultat

Att eleven tycker att laborationen är rolig

Att laborationen bygger på enkel utrustning, för det underlättar min förberedelse

Att laborationen bygger på enkel utrustning, för då blir det enklare för eleven att förstå vad de ska göra

Att jag gör samma laborationer som mina kollegor

Att eleverna făr träning i att planera en undersökning

Att eleverna får träning $i$ att analysera resultat och hitta samband

Att laborationen illustrerar begrepp som diskuteras i boken

Att eleverna får förståelse för ett experiment som spelat roll i fysikhistorien

Att eleverna kan visa att de uppnått något eller några av målen i kunskapskraven

Att laborationen bygger på datorstödd mätutrustning (eller motsvarande)

Övrigt:

Kommentar

5. Hur många år har du undervisat som fysiklärare? * Markera endast en oval.

0-5 år

5-10 år

10-20 år

20- 30 år

$30-40$ år

Mer än 40 år 
6. Ge gärna exempel på något annat som är viktigt för din planering av laborationsundervisningen

7. På vilket stadium undervisar du just nu? * Markera alla som gäller.

Gymnasiet

Universitet/högskola

Högstadie

Komvux

Övrigt:

8. I vilka ämnen undervisar du (förutom fysik)? * Markera alla som gäller.

Matematik

Data (till exempel programmering)

Kemi

Teknologi

Övrigt:

9. Jag är: Markera endast en oval.

Man

Kvinna

10. Hur fick du länken till denna enkät? Markera endast en oval.

Facebook

Genom en kollega

E-post-utskick

Övrigt: 